brought into association with each other and with Mr. Downs' stimulating and illuminating notes. Altogether it is an invaluable, indeed an indispensable collection. No other anthology approaches it in its field.

One can regret that the limitations imposed by the editor exclude some earlier statements of basic principle, as in the writings of Milton, Williams, Jefferson, and Mill, but they are easily available elsewhere. A greater latitude in including writings, especially judicial opinions, relating to newspapers and films and even comic books, when they are applicable in principle to books, would have permitted including opinions in such cases as Near $v$. Minnesota (a newspaper case establishing the "no prior restraint" principle), the Miracle and Lady Chatterley's Lover film cases, and the Winters case relating to comic books, all of which have had a significant role in protecting the freedom of books. "Admittedly," says the editor, the book "has a bias, reflecting the liberal view, as contrasted to the advocates of censorship." This bias, which I wholly applaud, together with the paucity of intellectually respectable defenses of censorship, has led to the failure to include any vigorous advocacy of censorship. Perhaps such advocacy has a place, even in a volume designed wholly to oppose censorship, if for no other reason than that there is hardly a better way to illumine the values of freedom than to allow a Comstock or a McCarthy or even a better-intentioned Postmaster General to advance the arguments for censorship.

These are trifling additions to wish for, however, in view of the abundance afforded in Mr. Downs' generous selection.

This volume is published by ALA, using the remainder of a grant from the Fund for the Republic that had supported the Freedom and Justice Awards. It is altogether fitting that ALA should be its publisher and Mr. Downs its editor. No professional association in the United States has more clearly distinguished itself in the defense and enlargement of the first freedom than ALA. And its struggle has been not only gallant, but also well-planned and successful. The ALA has not only fought battles for freedom; it has usually won them. That this is true is in major part due to the courage and judgment of Robert B. Downs. As president of the ALA during the McCarthy nightmare, as later chairman of the Intellectual Freedom Committee of that association, and now as editor of this volume, he has distinguished his procession as well as himself.-Dan Lacy, American Book Publishers Council.

\section{Cataloging Principles}

The Principles of Cataloguing. By L. Jolley, London: Crosby Lockwood \& Son Ltd., 1960. 147 p. 15s.

This little volume is so timely that those librarians particularly concerned with cata$\log$ code revision might wish it had appeared a few months, or even years, earlier. This is not to imply that its interest is limited to a few catalogers or even to catalogers only. In spite of its being at times pedantic, most librarians would find something of value in The Principles of Cataloguing. It is well written, although some of the idioms and choice of words sound strange to the American ear. "Whilst" and "amongst" indicate that the author was not educated in America. Mr. Jolley is an Australian, writing at the University of Glasgow, where a "programme for the revision of the catalogue" became the source of this work. Mr. Jolley also acknowledges his indebtedness to Charles A. Cutter, Seymour Lubetzky, and Andrew Osborn. In the preface, he says: "Cataloguing is one of those fields of human endeavor in which it may be safely assumed that if an idea is worth having, it will have occurred to more than one person."

Unquestionably the prime importance of Mr. Jolley's study is his discussion of topics under scrutiny by the ALA Catalog Code Revision Committee. The first chapter, "The Function of the Catalogue," presents one of the controversial topics to be discussed at the IFLA International Conference on Cataloguing Principles in October. He makes the statements, "The function of the catalogue is to interpret the library to the reader" and "The catalogue is an instrument of communication" and then repeats a few pages later, "The object of the catalogue is to serve the needs of the reader" and "The catalogue is an extremely complex communication system. It must therefore be based on existing habits." Throughout this chapter, he reiter- 
ates his basic principles by pointing out some of the major flaws in the 1949 ALA Code, which he says fails to present an orderly and consistent development of a few leading principles. "There is general agreement that it is cluttered up with overlapping and redundant rules." A clearer explanation for the need for a complete new code of rules could hardly be found. The assumption that the catalog should be all things is brushed aside by statements like, "The catalogue is only part of a whole system of bibliographical references.... There can be no doubt that cataloguers would save much trouble if they ceased to look on the catalogue as a reference tool always complete in itself. ... The author catalogue is not meant in any way to act as a biographical dictionary." It is unlikely that anyone would agree with all such premises, but in context they sound very convincing.

In succeeding chapters $\mathrm{Mr}$. Jolley discusses in detail principles that are sometimes difficult to grasp upon a first casual reading but which become quite logical and clearly stated when given careful and close attention. The chapter on corporate authorship is of particular interest because of the current discussions of the corporate concept in connection with the establishment of international cataloging principles. He says: "All existing codes are 'non-author headings' but not all in the same instances or for the same purposes. In many cases these headings can be regarded as an extension of a conventional title." And again: "To act as an author, a corporate body must not merely be intellectually responsible for a work, it must possess a name, it must have a defined if fugitive existence and an accepted name." These simple sentences demonstrate the lucidity of Mr. Jolley's approach to a complex problem.

Another chapter that has timely significance is the one on the subject catalog. Ever since the death of David Haykin, who was working on a subject heading code, catalogers have been expressing the desire and need for such a code. According to Mr. Jolley, "The reasons for this comparative neglect are to be found not in the lesser importance of the subject catalogue, but in the intractability of the difficulties it presents." In spite of other statements such as, "The subject catalogue can be judged only by the criterion of convenience and the best that can be attained is a number of approximately satisfactory entries," and "a general library can certainly function without a subject catalogue, but the possession of a subject catalogue is a great convenience," the chapter presents a lucid explanation of the difference between the subject heading catalog and the classified catalog and makes a definite contribution to the literature on subject headings. A discussion of "Uniterms," Ranganathan's concept of "chain procedure," and its use in the British National Bibliography is followed by the statement: "It must still be agreed that the union of chain procedure index and classification produces a combination as new as it is powerful."

In the chapter on descriptive cataloging, $\mathrm{Mr}$. Jolley first regrets that recent cataloging codes provide separate rules for author and title entries and for descriptive cataloging and then goes on to say that few British libraries have found it possible or desirable to indulge in all the detailed description prescribed by the Joint Code. He admits that the Library of Congress rules are valuable because of the guidance they give on the presentation of a standardized entry and then says they prescribe a degree of description few British libraries find necessary. Small public libraries can take comfort in the statement: "In descriptive cataloging the size of the library has a direct bearing on the catalogue entry."

Certainly all librarians concerned with catalog code revision will want to read this volume, and for all serious students of cataloging it should be required reading. It is highly recommended for those who would like to be brought up to date on current thinking about cataloging and the impetus behind code revision. Most catalogers will be grateful for one of $\mathrm{Mr}$. Jolley's closing statements: "Only harm can be done by setting standards which are impossibly high. No code can make certain that every book is everywhere catalogued in the same way. No catalogue can succeed always in bringing together all the works of one author, or all editions of one work. What the cataloguer can hope to do is construct a catalogue on such lines that it will be a source not of confusion, but of instruction to its users."Orcena Mahoney, Executive Secretary, Resources and Technical Services Division, $A L A$. 